\title{
Bark thickness and fire regime: another twist
}

\author{
Juli G. Pausas \\ CIDE-CSIC, Ctra. Naquera Km. 4.5 (IVIA), Montcada, \\ Valencia 46113, Spain (tel +34 963 424124; email \\ juli.g.pausas@ext.uv.es)
}

Bark is the outermost covering of stems in woody plants and plays a fundamental protective role. Recently I hypothesized that 'at the global scale, a significant proportion of the variability in bark thickness is explained by the variability in fire regimes' , and specifically predicted that frequent low intensity fires select for thick bark (Pausas, 2015). In addition, I suggested that differentiating between inner and outer bark thickness would help us gain a better understanding of the functional role of bark, especially in nonfire prone ecosystems. Based on an understanding of the selection pressure by fire and on other plant traits, I showed that some fire regimes select for thick bark at the base of the trunk, others select thick bark on the whole plant (stem, branches, twigs), while other fire regimes do not select for thick bark - and thus relatively thin barks are the more likely to be observed (Table 1). However, the paucity of available data at a global scale limited an empirical demonstration of the proposed framework.

A new paper has now provided evidence for the fire hypothesis of bark thickness at a global scale. Rosell (2016) sampled bark thickness in woody species from 18 sites in different climates and fire regimes, and has demonstrated that fire regime was the main environmental factor explaining variability in bark thickness (after accounting for plant size; Fig. 1). But perhaps the most valuable

contribution of Rosell is that, in addition to total bark thickness, she accurately measured inner and outer bark thickness, and showed that they behave differently: the role of fire is especially relevant for explaining outer bark thickness (Fig. 1; see Schafer et al., 2015, for similar results), while inner bark does not seem to provide protection for the cambium from heat. This provides a step forward in our understanding of the ecology of bark. These results were found despite the relatively simple estimation of fire regime (semiquantitative fire frequency, 1-5), compared with alternative parameters (climate) that were more precise and variable. This simple estimation of fire regime is understandable as fire history is not as available as climate data (remotely-sensed fire activity could be a possible source; Pausas \& Ribeiro, 2013). Below I take the opportunity to comment on how we could advance our understanding of the role of fire in shaping bark thickness by considering more detailed fire regime information coupled with some plant lifehistory traits.

Fire regime is the complex combination of fire characteristics that prevails in a given area, and includes frequency, intensity, seasonality and type of fuels consumed (Keeley et al., 2012). For its relevance in relation to the bark, I will focus on first fire frequency, defined as the fire return interval in relation to plant longevity; and second on the fire intensity, defined as the flame height in relation to the height of canopy fuels. The latter variable defines two very contrasted fire regimes: understory (or surface) fires (i.e. when the flame height is lower than the overstory; crowns are not consumed by the fire) and crown fires (otherwise). This distinction is important because the predictions of bark thickness differ in these two fire regimes (Table 1), and the linear expectation of bark thickness and fire frequency may not apply when mixing understory and crown fire regimes. In fact, Rosell showed that Mediterranean ecosystems have thin barks despite frequent fires; this is exactly the prediction for those ecosystems as they are subject to frequent crown fires (Table 1; Fig. 3 in Pausas, 2015). Stating that fire regimes explain an important part of the variability in bark thickness does not mean that bark thickness and fire frequency should show a strong positive correlation; for example, the high frequency of understory fires selects for thick basal bark in trees but not in the coexisting understory plants; and the high frequency of crown fires does not select for thick bark at all (Keeley \& Zedler, 1998; Pausas, 2015). In fact, I expect bark thickness to be related to the frequency of low intensity fires (Pausas, 2015). When Rosell analysed her data separating short $(<2 \mathrm{~m})$ and tall $(>2 \mathrm{~m})$ species, the effect of fire on bark thickness disappears in the former and increases in the latter (Fig. 1). This is probably because many of the short species grow in shrublands subject to crown fires or are in the understorey of forests; in such cases thin barks are expected

Table1 Predicted total bark thickness in relation to the fire regime (Pausas, 2015)

\begin{tabular}{|c|c|c|}
\hline Fire regime & Examples & $\begin{array}{l}\text { Prediction of bark } \\
\text { thickness }\end{array}$ \\
\hline $\begin{array}{l}\text { Frequent surface fires in } \\
\text { forests and woodlands }(A)\end{array}$ & $\begin{array}{l}\text { Southern North } \\
\text { American pine } \\
\text { forests }\end{array}$ & $\begin{array}{l}\text { Trees with thick } \\
\text { basal bark, } \\
\text { understory } \\
\text { shrubs with thin } \\
\text { bark }\end{array}$ \\
\hline $\begin{array}{l}\text { Frequent grass-fuelled } \\
\text { surface fires in open } \\
\text { ecosystems (B) }\end{array}$ & African savannas & $\begin{array}{l}\text { Trees with moderate } \\
\text { bark thickness }\end{array}$ \\
\hline $\begin{array}{l}\text { Frequent tall grass-fuelled } \\
\text { fires affecting crowns (C) }\end{array}$ & $\begin{array}{l}\text { Brazilian savannas } \\
\text { (cerrado) }\end{array}$ & $\begin{array}{l}\text { Trees and shrubs } \\
\text { with thick bark in } \\
\text { the stem and } \\
\text { branches }\end{array}$ \\
\hline $\begin{array}{l}\text { Frequent high-intensity, } \\
\text { woody-fuelled crown fires } \\
\text { in forests and shrublands (D) }\end{array}$ & $\begin{array}{l}\text { Mediterranean } \\
\text { shrublands }\end{array}$ & Thin bark \\
\hline $\begin{array}{l}\text { Infrequent drought-driven } \\
\text { high-severity fires (E) }\end{array}$ & $\begin{array}{l}\text { Rainforests, cold } \\
\text { temperate forests }\end{array}$ & Thin bark \\
\hline $\begin{array}{l}\text { Infrequent fuel-limited } \\
\text { fires }(F)\end{array}$ & Arid ecosystems & Variable \\
\hline
\end{tabular}




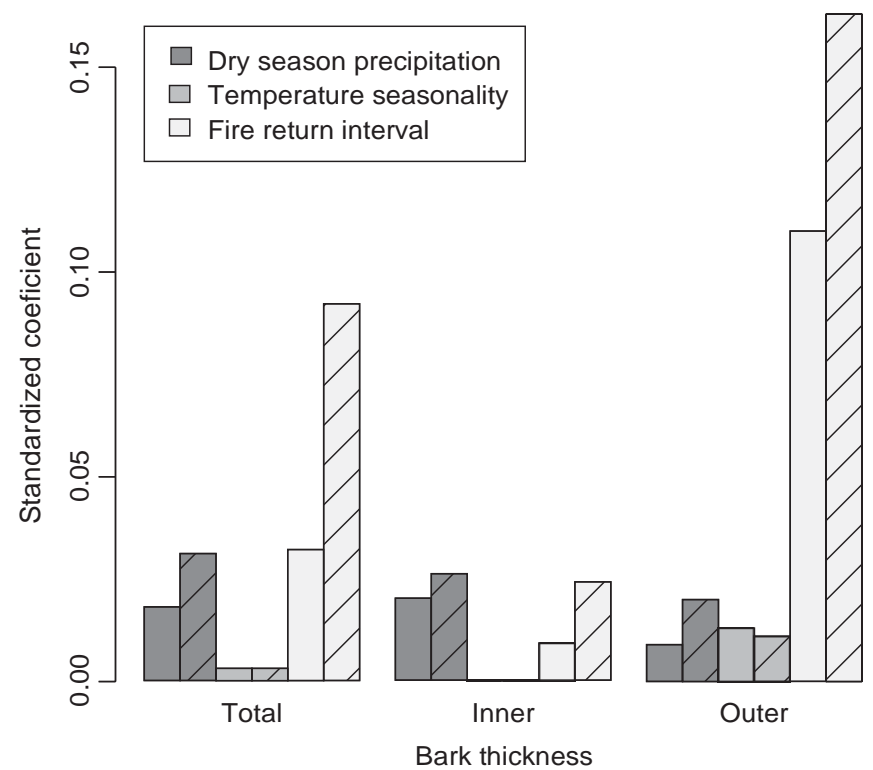

Fig. 1 Relative role of climate (dry season precipitation and temperature seasonality) and fire (fire return interval) in determining bark thickness (total, inner, outer bark thickness) based on c. 500 species from 18 communities distributed worldwide (Australia, Brazil, California (USA), Italy and Mexico). Values are the squared standardized coefficients of multiple regression modelsafteraccounting forstem diameter(fromRosell, 2016). Climaticdata were quantitative (in millimetres and ${ }^{\circ} \mathrm{C}$ ), fire regime data were semiquantitative(1-5). Barswithstripes refertotheresultswhentheanalysis is restricted to species taller than $2 \mathrm{~m}$.

(Table 1); by contrast, trees taller than 2 m may include a wide variability of conditions (from trees in fire-free wet forests to trees under surface fire regimes where thick bark is expected). Therefore, the results of splitting species by growth form are also congruent with the predictions and further support the role of fire in shaping bark thickness (Pausas, 2015).

These results suggest that to understand bark thickness it is necessary to account for different fire regime components coupled by some plant traits (Fig. 2). A thick fire-protective bark is expected when fire return intervals are shorter than the lifespan of the plant, and the flame height is shorter than the height of the base of the canopy (i.e. when there is a gap between surface fuels and canopy fuels; e.g. surface or understory fires). The same fire frequency may select for thick bark where the flame is small in relation to the plant (surface fires in forests), or for thin bark where the flame burns the canopy (i.e. crown fires like those occurring in the Mediterranean shrublands). In fact, we would expect a thicker bark in relation to the stem diameter as the flame height increases (in relation to the canopy height) in low intensity fire regions (grass-fuelled surfacefires - the grey area in Fig. 2). In an ecosystem with long fire intervals, a thick bark may still be relevant but for only the longlived plants; this may explain the occurrence of bark protected plants in some arid ecosystems (Cousins et al., 2016; Schubert et al., 2016), and the high variability of bark thickness in these ecosystems (Table 1). However, the variability in bark thickness of most species in arid ecosystems may be shaped by factors other than fire (such as water control or structural stability; see Paine et al., 2010; Rosell et al., 2014; Pausas, 2015; Richardson et al., 2015).

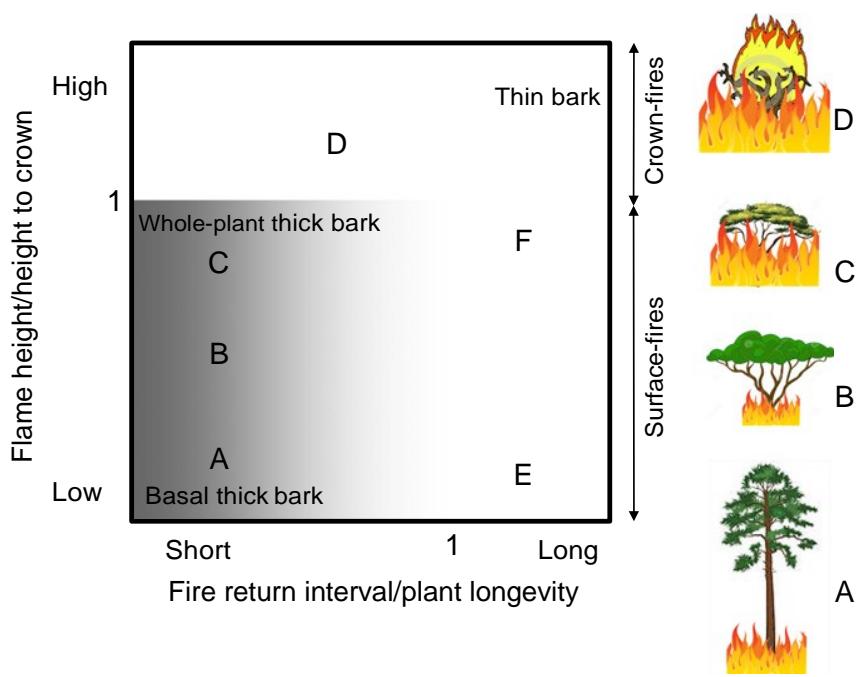

Fig. 2 Bark thickness as a function of fire regime: flame height (an indicator of fire intensity) and mean fire return interval (fire frequency). Fire regime is scaled by the characteristics of the plant (height to the base of the crown and longevity, respectively). The shaded area represents the areas where thick barksareadaptiveforfireprotection, thatis, when returnintervalsareshorter than the lifespan of the plant and fires are oflowintensity (flame height is shorter than the distance to the base of the crown, e.g. surface fires); the shaded area is limited by thresholds (values of 1 on the axes). The unshaded arearepresents the conditionswherethickbarks are notadaptive(thinbark is more likely), that is, when fires are crown-fires or when the return interval is long (in relation to the longevity of the plant). Letters A-F represent the approximatelocation of the dominantwoodyspecies of the sixfire regimes in Table 1, and the drawings on the right illustrate the scenarios A-D.

To what extent these patterns (Fig. 2) are driven by the outer bark only remains unknown, but the research by Rosell points in that direction. Validating the model in Fig. 2 may not be easy, but it does show that a linear relation between fire frequency and bark thickness is not necessarily the expectation; thresholds do exist. In any case, I hope it may help to redefine further research in this topic.

Bark thickness is a key trait structuring many woody plant communities in ecosystems subject to fire. It is especially relevant in tropical ecosystems where there is a bark thickness threshold that allows the plant to enter frequently burnt communities (Hoffmann et al., 2012); consequently, average bark thickness is strongly associated with fire regime and with many other community attributes (e.g. forest-savanna transitions; Dantas et al., 2013). Thin-barked trees enter in the community when fire intervals are long, as can be observed in ecosystems subjected to strong fire exclusion regimes (Harmon, 1984; Gilliam \& Platt, 1999; Peterson \& Reich, 2001). Thus, intra-site variability is expected in transition zones and very dynamic systems or where plant longevity is very variable (Fig. 2). In addition, thin- and thick-barked plants can coexist under a given fire regime because there are alternative mechanisms for fire survival, such as other stem-protective mechanisms different from having a thick bark (e.g. Burrows, 2002; Gagnon et al., 2010), or moving buds underground (e.g. Maurin et al., 2014; Paula et al., 2016). This is especially relevant in highly diverse ecosystems where different lineages may have evolved different 'solution' to a given 'problem' . That is, not all species in a given fire regime may 
have acquired a thick bark, just as not all species living in grazing systems have evolved thorns.

Overall, fire regime is not expected to explain 100\% of the variance of bark thickness, even in fire-prone ecosystems; but it does explain a very important proportion of the variance especially when the different components of fire regimes are taken into account (see Fig. 2). The work by Rosell, when framed in relation to the selection processes of bark thickness, represents a step forward in understanding the ecology of bark at a global scale, and on the relative role of fire in shaping bark thickness. Thus, we are gaining a more complete understanding of stem defence strategies in plants.

Juli G. Pausas

\section{References}

Burrows GE. 2002. Epicormic strand structure in Angophora, Eucalyptus and Lophostemon (Myrtaceae) - implications for fire resistance and recovery. New Phytologist 153: 111-131.

Cousins SR, Witkowski ETF, Pfab MF. 2016. Beating the blaze: fire survival in the fan aloe (Kumara plicatilis), a succulent monocotyledonous tree endemic to the Cape fynbos, South Africa. Austral Ecology 41: 466-479.

Dantas VL, Batalha MA, Pausas JG. 2013. Fire drives functional thresholds on the savanna-forest transition. Ecology 94: 2454-2463.

Gagnon PR, Passmore HA, Platt WJ, Myers JA, Paine CET, Harms KE. 2010. Does pyrogenicity protect burning plants? Ecology $91: 3481-3486$.

Gilliam FS, Platt WJ. 1999. Effects of long-term fire exclusion on tree species composition and stand structure in an old-growth Pinus palustris (Longleaf pine) forest. Plant Ecology 140: 15-26.

Harmon ME. 1984. Survival of trees after low-intensity surface fires in Great Smoky Mountains National Park. Ecology 65: 796-802.
Hoffmann WA, Geiger EL, Gotsch SG, Rossatto DR, Silva LCR, Lau OL, Haridasan M, Franco AC. 2012. Ecological thresholds at the savanna - forest boundary: how plant traits, resources and fire govern the distribution of tropical biomes. Ecology Letters 15: 759-768.

Keeley JE, Bond WJ, Bradstock RA, Pausas JG, Rundel PW. 2012. Fire in Mediterraneanecosystems:ecology, evolutionand management.Cambridge,UK: Cambridge University Press.

Keeley JE, Zedler PH. 1998. Evolution of life histories in Pinus. In: Richardson DM, ed. Ecology and biogeography of Pinus. Cambridge, UK: Cambridge University Press, 219-250.

Maurin O, Davies TJ, Burrows JE, Daru BH, Yessoufou K, Muasya AM, van der Bank M, Bond WJ. 2014. Savanna fire and the origins of the 'underground forests' of Africa. New Phytologist 204: 201-214.

Paine CET, Stahl C, Courtois EA, Patino S, Sarmiento C, Baraloto C. 2010. Functional explanations for variation in bark thickness in tropical rain forest trees. Functional Ecology 24: 1202-1210.

Paula S, Naulin PI, Arce C, Galaz C, Pausas JG. 2016. Lignotubers in Mediterranean basin plants. Plant Ecology 217: 661-676.

Pausas JG. 2015. Bark thickness and fire regime. Functional Ecology 29: 315-327.

Pausas JG, Ribeiro E. 2013. The global fire-productivity relationship. Global Ecology and Biogeography 22: 728-736.

Peterson DW, Reich PB. 2001. Prescribed fire in oak savanna: fire frequency effects on stand structure and dynamics. Ecological Applications 11:914-927.

Richardson SJ, Laughlin DC, Lawes MJ, Holdaway RJ, Wilmshurst JM, Wright M, Curran TJ, Bellingham PJ, McGlone MS. 2015. Functional and environmental determinants of bark thickness in fire-free temperate rain forest communities. American Journal of Botany 102: 1590-1598.

Rosell JA. 2016. Bark thickness across the angiosperms: more than just fire. New Phytologist 211: 90-102.

Rosell JA, Gleason S, Mendez-Alonzo R, Chang Y, Westoby M. 2014. Bark functional ecology: evidence for tradeoffs, functional coordination, and environment producing bark diversity. New Phytologist 201: 486-497.

Schafer JL, Breslow BP, Hohmann MG, Hoffmann WA. 2015. Relative bark thickness is correlated with tree species distributions along a fire frequency gradient. Fire Ecology 11: 74-87.

Schubert AT, Nano CEM, Clarke PJ, Lawes MJ. 2016. Evidence for bark thickness as a fire-resistance trait from desert to savanna in fire-prone inland Australia. Plant Ecology 217: 683-696. 